\title{
The Aftermath of Quantitative Easing in Advanced Economies: The Empirical Evidences
}

\author{
Prof. Dr. Harun Bal (Çukurova University, Turkey) \\ Ph.D. Candidate Shahanara Basher (Cukurova University, Turkey) \\ Ph.D. Candidate Abdulla Hil Mamun (Çukurova University, Turkey)
}

\begin{abstract}
Quantitative easing (QE), as a measure of unconventional monetary policy (UMP), has been followed by many of the central banks of advanced economies to boost the economy by stimulating investment and consumption. The study identifies the most recent QE programs undertaken by central banks of four major advanced economies, namely, Federal Reserve (Fed), Bank of England (BOE), Bank of Japan (BOJ) and European Central Bank (ECB), and examines its impact on major macroeconomic indicators, namely output growth, inflation, exchange rate indices and stock market indices, employing vector autoregressive (VAR) models. Findings of the study suggest that QE was only favorable for real GDP growth of USA and the development of stock market of euro area. However, such an UMP failed to bring about changes in appropriate directions among the other economic indicators of these advanced economies. QE at an adequate scale to offset the recessionary forces could help achieve the expected results of the policy action. At the same time, policy makers should think over other supplementary measures that can support and expedite the impact of QE in favourable directions to achieve the desired goals of such UMP.
\end{abstract}

\section{Introduction}

In order to deal with the financial crisis in 2008, many of the central banks round the world have pursued different unconventional monetary policies (UMP) to boost up their economies, primarily through the purchase of longduration assets in the name of large scale asset purchase programs (LSAPs) (Maggio et al., 2016). Among the largest central banks of the world in the advanced economies, monetary easing or quantitative easing (QE) of the US Federal Reserve (Fed), the Bank of England (BOE), the Bank of Japan (BOJ), and the European Central Bank (ECB) has drawn particular attention of researchers particularly because of its widespread impact on respective economies. All these four central banks have embarked on QE in the shade of UMP so as to inject more money into the economy to combat against economic downturn. QE is expected to be effective in stimulating the economy by influencing banks to offer more loans lowering interest rates. The view is that banks buy assets taking new money to replace the assets they have sold to the central bank. It results in rise in stock prices and fall in interest rates, which consequently boosts investment and consumers' spending, and thereby aggregate demand. Regardless of the recent worldwide popularity of LSAPs, the degree to which they are effective in producing anticipated result and the channels by which they affect the real economy have been at the core of a policy and academic discussion (Maggio et al., 2016).

The academic debate on the success of QE is largely dominated by the notion of "liquidity trap".

If banks consider short- term risk- free assets (government bonds in particular) and central bank money mostly identical at the zero lower bound on interest rates, purchases of assets by central banks will than cause banks holding of short- term government bonds to fall and rise in the amount of money hoarded by central bank correspondingly. Purchases of these assets for monetary policy purposes would then be "neutral" in that they would have no effect on real economic activity and goods prices (Bundesbank, 2016).

In the aftermath of global financial crisis, there was limited scope to insert additional money into the economy by lowering policy rates as it was almost near to zero in most of the industrialized advanced economies (Hausken $\&$ Ncube, 2013). It drives the policy makers to sort out an unconventional way so as to work as a propeller to put more money into the economy. Policy makers vote for lowering the long-term interest rate through the LSAPs of central banks to fight the recession. QE or LSAPs, generating a decreasing tendency in term premium or stimulating inflation expectation, alters long-term interest rate (Joyce et al., 2012). Such an UMP has thus been accepted to be taken on unusual situations (Bouraoui, 2015).

If we examine episodes across countries, there is prudently clear evidence that QE programs have lowered yields on long-term government debt. The APPs of central banks cause bond prices to rise and yields to drop since they are correlated inversely. As most of the central banks pursued QE to combat great depression in 2008, Figure 1 shows that yields of long term bond declined in the following years.

In japan, long term bond yields have been falling since the great depression of 2008. After the expansion of QE in April 2013, bond yields dropped below 5 percent and turn into negative all through 2016. Bond yield in euro area was around 3.5 to 4.5 percent through 2008 to the second quarter of 2012 and was nearly 3 percent till December 2013. Following the global crisis of 2008, bond yields decreased from over 5 percent to below 3.5 percent, but apart from the theoretical expectation, it remained stable around 2 to 3 percent during and beyond the 
course of QE program and then again started to fall from the beginning of 2015. Most exceptionally, US bond yields jumped by more than 1 percent to 2.74 percent in first 10 months after the implementation of APPs in December 2012, however, again registered a decline in the preceding months till late 2016.

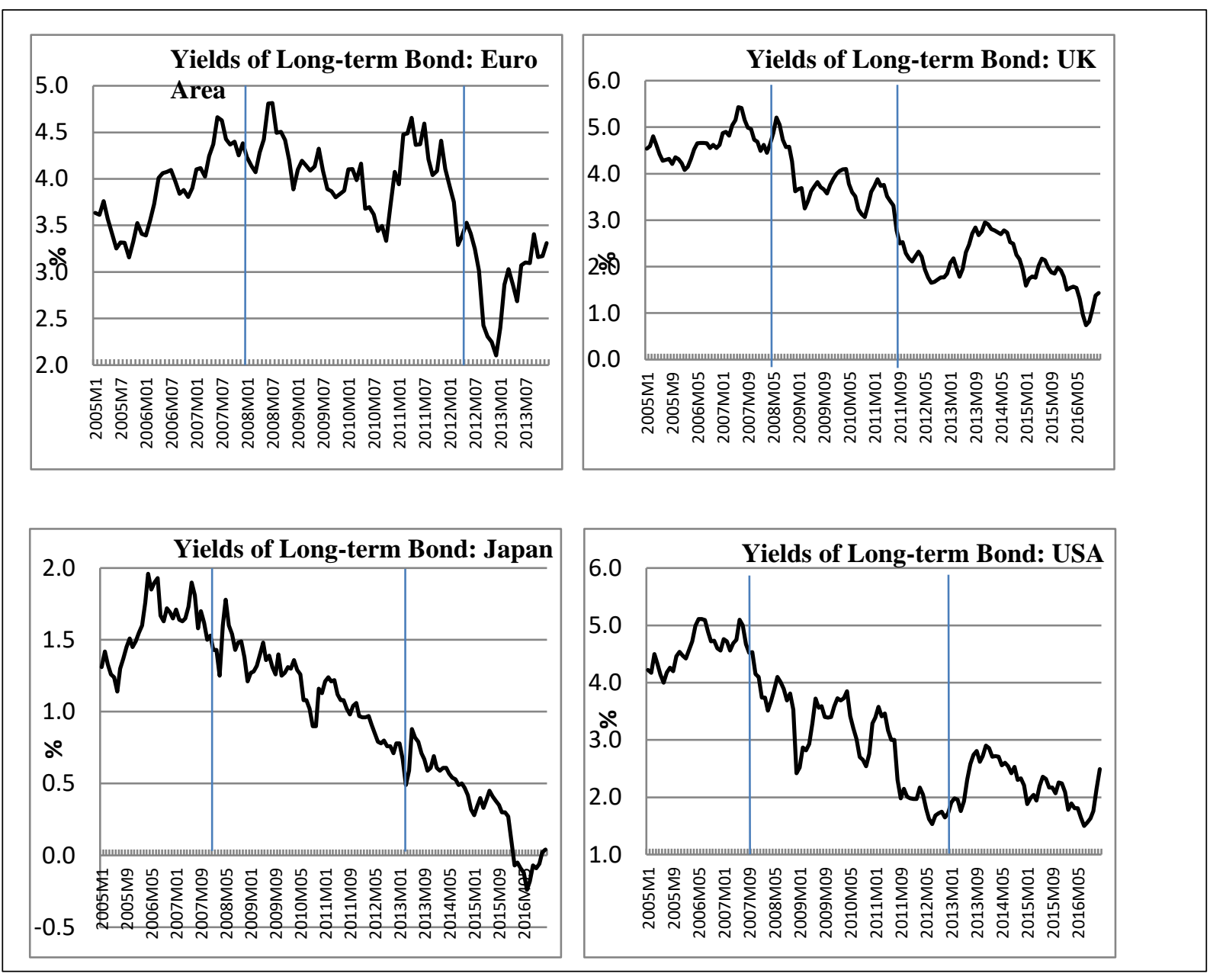

Figure 1: Long-term Bond Yields Source: OECD, Main Economic Indicators (database), http://dx.doi.org/10.1787/data-00052-en (Accessed on June 20, 2018)

Through vast amounts of asset purchases, the central bank can still promote total output and prices by liquidity enhancement even in situation when the lower round of short-term interest rate is clogged near to zero (Mishkin 1996). A greater monetary based confirmed by increased liquidities reduce term premium through Tobin's (1969) portfolio balance channel. Alternatively, stoking inflation expectations by 'committing to be irresponsible' is another channel through which LSAP might work (Eggertsson, 2006).

Irrespective of the channel, QE should have a positive effect on the economy as a whole. The drop in real interest rate is expected to have a satisfactory influence on consumer spending and business investments. QE interventions have also inclined to be associated with fluctuations in prices of other asset, such as equities, corporate bonds and exchange rates. The interventions of central banks at an unprecedented scale have become a key and recent area of study by central banks, researchers and market experts alike. There have been a significant number of recent studies assessing the impact of QE. The aim of QE by all these four central banks was to boost the economy by stimulating investment and consumption. The main purpose of the study is to investigate the impact of QE on a range of macroeconomic indicators of these advanced economies. In this regard, the study identifies the most recent $\mathrm{QE}$ programs of central banks of the aforementioned economies and then evaluates the impacts on major economic indicators, namely output growth, inflation, exchange rate indices and stock market indices, based on VAR models. Assessing what would have occurred to these economies in the absence of QE programs is one of the major interests of this study. 


\section{QE: Channels of Operation}

Central bank purchases assets most of which are government bonds, as it has a large market and thus offer opportunity to buy bulk quantities of them fairly quickly. Central banks asset purchase program injects money into the economy through different ways that can be explained using the Figure 2.

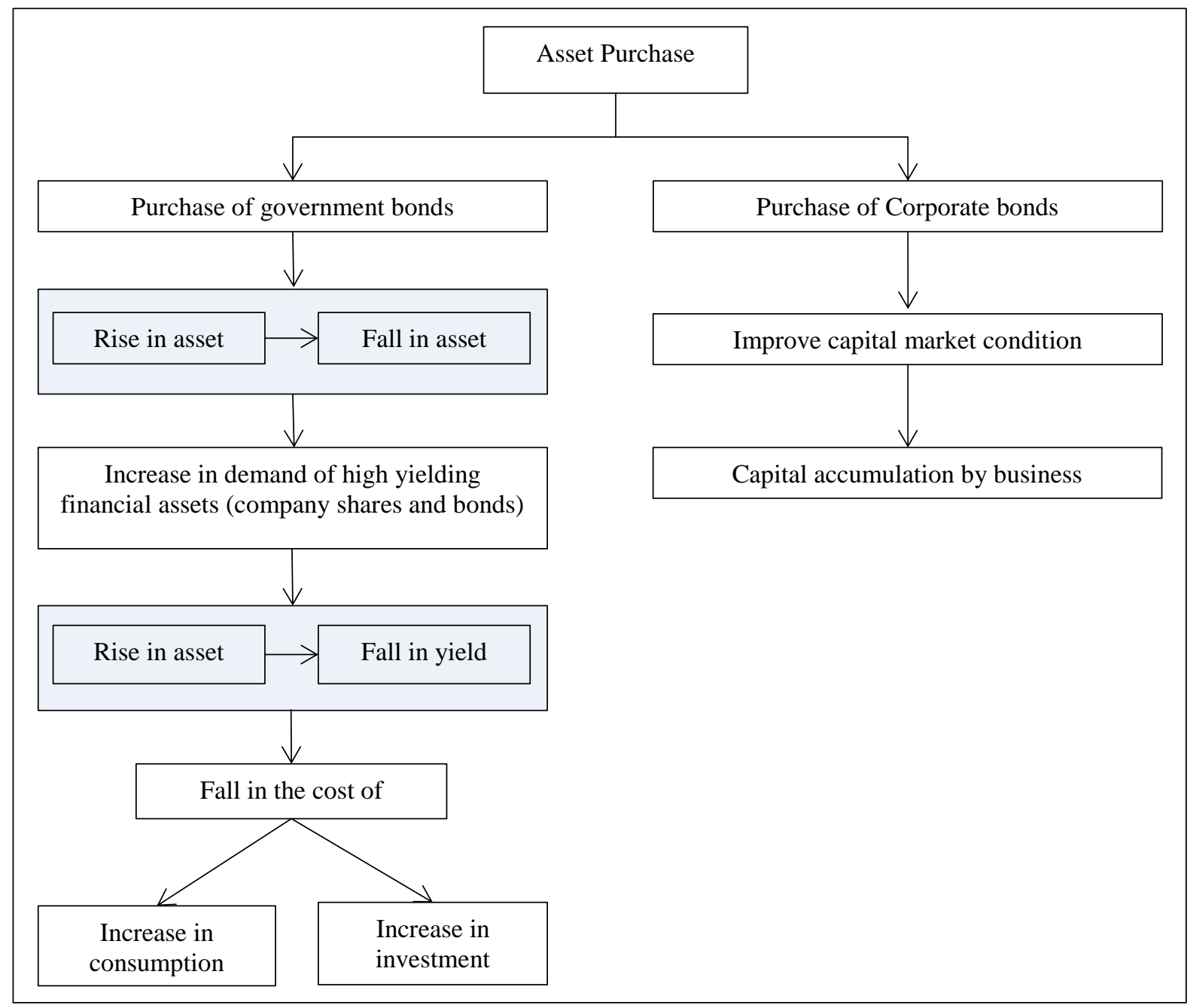

Figure 2: QE: As a Means to Stimulate the Economy Source: Developed by Authors

Purchase of government bonds that reduce yields of financial assets of both government and private firms can stimulate economic activity by raising consumer spending and investment. Again, buying corporate bonds, central banks help develop stock market which eventually supports businesses to accumulate capital.

The channels through which QE influences macroeconomic developments are much alike conventional interest rate policy. It works similar to the way that asset prices or yields are affected by purchases of government bonds (Bundesbank, 2016). The probable channels through which QE may be expected to work are explained below.

QE policies like LSAPs are seemed to have beneficial impact in reducing long-term bond yields when nontraditional monetary policy serves as a credible commitment by the central bank to maintain low interest rates even after the economy recovers (Eggertson, 2003). Central banks can achieve such an obligation in QE by purchasing assets of long duration in a large denomination (Clouse, et. al., 2000). CB's readiness to commence an unconventional policy like QE affects interest rates of bond market as it signals that the period of low policy rate $\mathrm{CB}$ plans to hold is going to be prolonged. Consequently, long- term interest rates would remain to fall according to the expectations hypothesis which will bring about a positive impact on credit demand and thereby stimulate aggregate demand and increase inflation. The same impact can be produced through the purchases of long-term bonds with greater duration by commercial banks to adjust their portfolios in response to the drop in long-term yield caused by LSAPs of CB in order to maintain their optimal profitability and risk structure, the so called portfolio rebalancing channel. On the other hand, liquidity channel asserts that QE raises yields on the most liquid bonds by reducing liquidity premium increasing the liquidity in the hand of investors. According to the bank capital and balance sheet channel, asset purchases surge asset prices and so does the assets of a bank, which ultimately make commercial banks' able to fulfil the higher capital requirement of growing loan portfolio raising their capital. 
It has a stimulating effect on external financing both by banks and borrowers and hence promotes aggregate demand and inflation. On exchange rate channel of $\mathrm{QE}$, an asset purchase program may result in depreciation of domestic currency by reducing domestic currency denominated assets' yield and their demand to foreign investors that may help achieve competitiveness of domestic goods and thereby spur domestic aggregate demand and inflation.

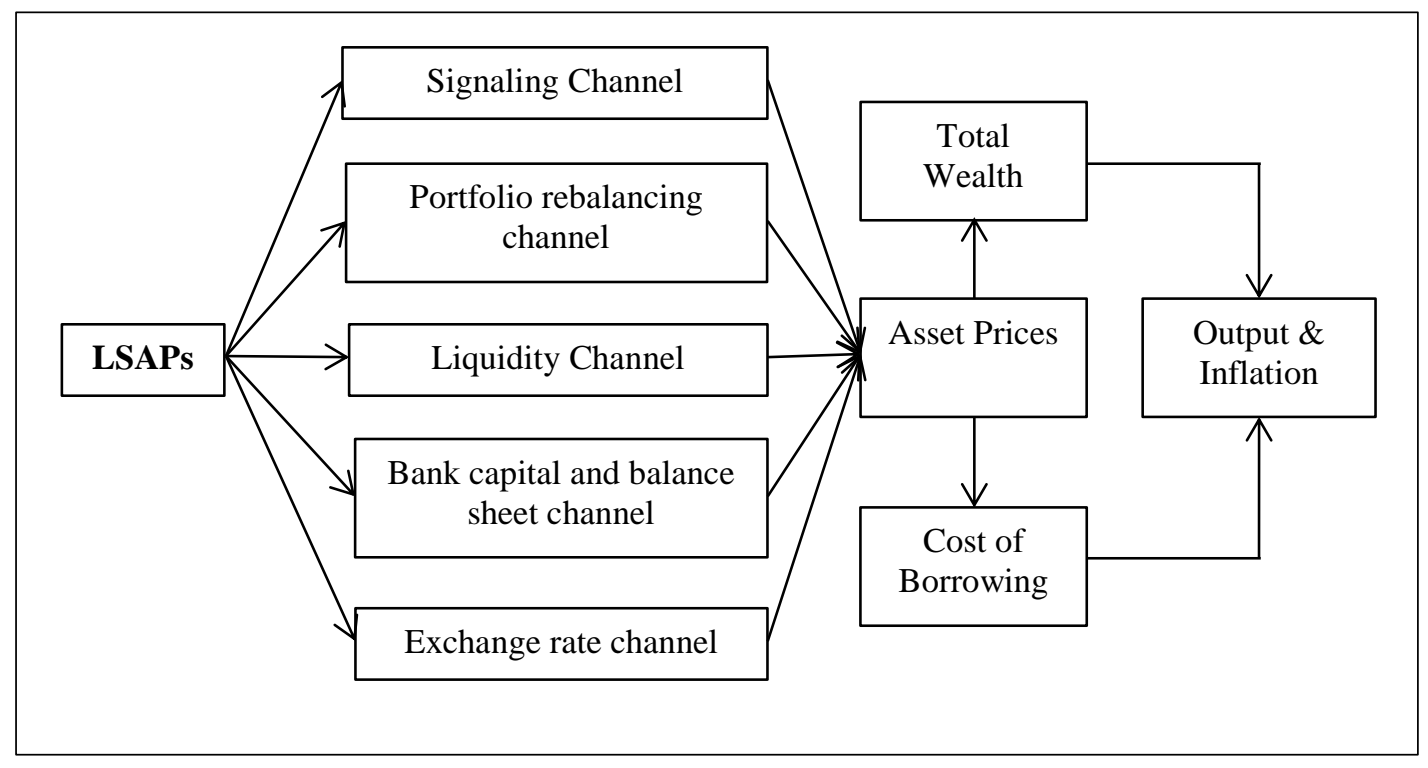

Figure 3: Transmission Channels of QE Source: Developed by Authors

\section{QE: A Brief Review}

QE started with the purchase of government bonds supported by the creation of central bank reserves of BOJ in 2001. Following Japan, the US Federal Reserve and the BOE adopted QE in 2008 and 2009, as they neared the lower bound for nominal interest rates and desired to supply additional monetary stimulus. In 2015, the ECB as well started escalating its balance sheet as it approached the lower bound for interest rates. Three of these four central banks were continuing to expand their balance sheets in the second half of 2016 (Haldane et al., 2016).

\section{a. QE of BOJ}

The economy of Japan has been locked in a liquidity trap since the mid-90s. Since then different strategies has been adopted by the BOJ to fight the recession and boost-up the economy (Michaelis \& Watzka, 2017). BOJ bought government securities from the banking sector so as to enhance cash reserves held in the banking system which was not possible by reducing the money market interest rates as they had already been at their Zero Lower Bound. It was expected that the high level of reserves would be adequate for ensuring higher liquidity in the broader economy and thereby raise asset prices and eliminate forces causing deflationary pressure. Apart from the purchase of government bonds in response to the financial crisis, BOJ also purchased corporate bonds to stimulate businesses. BOJ increasingly increases the scale of its comprehensive monetary easing to as much as $¥ 101$ trillion by the end of 2012. More recently, in April 2013, the announcement of the expansion of asset purchase program of BOJ by 60 to 70 trillion Yen a year popularized as Abonomics possibly the largest monetary easing in recent history with the purpose to double the monetary base in two years by purchasing government bonds aggressively, exchange-traded funds, as well as real estate investment trusts with the hope to bring Japan from deflation to inflation, aiming for $2 \%$ inflation. Later, the BOJ declared further extension of its bond purchasing program to yearly 80 trillion Yen of bonds in October 2014.

\section{b. QE of FED}

Fed implemented a series of $\mathrm{QE}$ to deal with the crisis. It was the most active central bank in implementing LSAPs in several rounds. The first round of QE that aims to stabilize the financial market and US economy from the financial crisis was declared and put into effect in November 2008 under which $\$ 600$ billion mortgage-backed securities was purchased by Fed. The second round of Fed's QE that includes purchase of US Treasury securities by the amount of $\$ 600$ billion started in November 2010. The final round of QE implemented by Fed was launched in September 2012 which involved monthly \$85-billion booster through buying mortgage-backed and longer-term Treasury securities. The Fed buys government or other bonds and then makes this money available for banks to borrow, thereby expanding the amount of money circulating in the economy, which in turn reduces long-term interest rates. Fed starts to compress the program as the "tapering" takes root at the beginning of 2014 and announces the historic end to the program from October 2017. 


\section{c. QE of BOE}

BOE's launched QE by undertaking its LSAPs between March 2009 to January 2010 and October 2011 to July 2012. Starting in March 2009, the BOE had purchased nearly $£ 165$ billion in assets as of September 2009 and about $£ 175$ billion in assets by the end of October 2009. On November 2009, the Monetary Policy Committee supported to expand asset purchases to $£ 200$ billion. Though the Bank has purchased limited quantities of high-quality private-sector assets, but the assets purchased have been dominated by UK government securities. In December 2010, BOE called for another $£ 50$ billion extension of QE program, while there was dispute for an increase in interest rates due to inflation being above the $2 \%$ target rate. In October 2011, the BOE declared another round of QE, creating an additional $£ 75$ billion. In February 2012 an additional $£ 50$ billion APPs is announced and in July 2012 another $£ 50$ billion is declared, taking the amount to $£ 375$ billion in total. In August 2016 , the BOE announced to buy an additional $£ 60$ billion of UK government bonds and $£ 10$ billion of corporate bonds addressing ambiguity over Brexit and uncertainties about productivity and economic growth.

\section{d. QE of ECB}

Following the lead of the United States, the United Kingdom and Japan, the ECB has announced its programme of QE on 22 January 2015 and has started purchases of treasury bonds and other bonds by the amount of $€ 60$ billion every month in the QE framework from March 2015. ECP expands its APPs to $€ 80$ billion per month in March 2016 and announces that it will continue its QE programme until the end of 2017. From April 2017, QE program is cut to $€ 60$ billion a month from April 2017. In a recent declaration on October 2017, ECB reduces its current monthly purchase of $€ 60$ billion to a new monthly purchase of $€ 30$ billion from January 2018 until the end of September 2018.

\section{Performance of the Major Economic Indicators Following Recent QE}

\section{a. Asset-GDP Ratio}

In response to the Great Recession, all major central banks approved several UMPs intended to foster a more robust economic recovery. Of these policies, LSAPs, that is "QE", led to the largest expansion of the balance sheet of these central banks which is evident from Figure 4 as it is observed that there were sharp rises in asset-GDP ratio of FED, $\mathrm{BOE}, \mathrm{BOJ}$ and $\mathrm{ECB}$. The central banks continue and regularly revised their asset purchase program to achieve economic resilience. As the study is concerned with the most recent QE programs undertaken by the banks addressed above, Figure 4 illustrates that there is an increase in asset-GDP ratio of the banks immediately after the approval of their APPs.

Just after the announcement of an increase in the amount of open-ended purchases from $\$ 40$ billion to $\$ 85$ billion per month by the Federal Open Market Committee of Fed On December 2012, asset-GDP ratio of Fed increased from 17.84 percent to 25.07 percent over the next ten quarters. For the case of BOE, expanded APPs was announced and revised from last quarter of 2011 through third quarter of 2012. In response to this statement, assetGDP ratio of BOE increased from 70.34 percent in the last quarter of 2011 to 93.03 percent in the second quarter of 2013 .

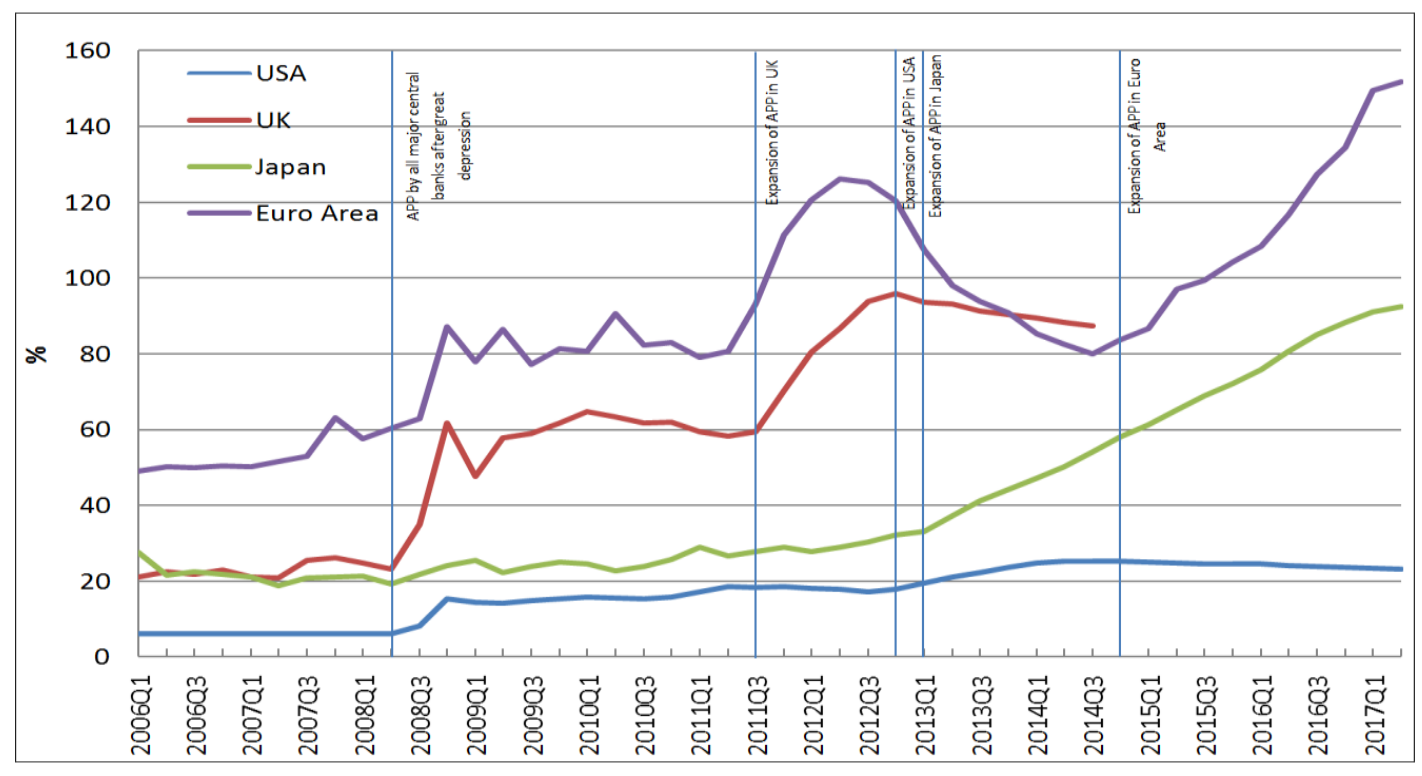

Figure 4: Total Assets as Percent of GDP Source: European Central Bank and FRED, https://fred.stlouisfed.org/series/ECBASSETS, Accessed on June 20, 2018. 
After the major expansion statement of asset purchase by BOJ in April 2013 by 60 to 70 trillion Yen a year and which was further extended to 80 trillion Yen a year in October 2014 that has still been in effect, its asset-GDP ratio started to jump from 37.22 percent in second quarter of 2013 to 92.51 percent in the second quarter of 2017. Massive APPs of ECB amounting to $€ 60$ billion per month of euro-area bonds was declared in January 2015 and it was long drawn and increased to $€ 80$ billion on March 2016. Consequently, asset-GDP ratio that was 86.57 percent in January 2015 reached to 151.74 percent in April 2017.

\section{b. Inflation}

Another objective of QE is to keep inflation on track to meet the 2 percent target inflation rate set by the governments of the economies to stimulate business and consumer confidence. Critical examination of the annual inflation of the economies under investigation reveals that except for Japan, year-to-year trend of inflation are very similar for UK, USA and Euro Area. However, QE of the central banks were successful in attaining inflation targets in the short and over the medium term, but fail to perform better in the long run.

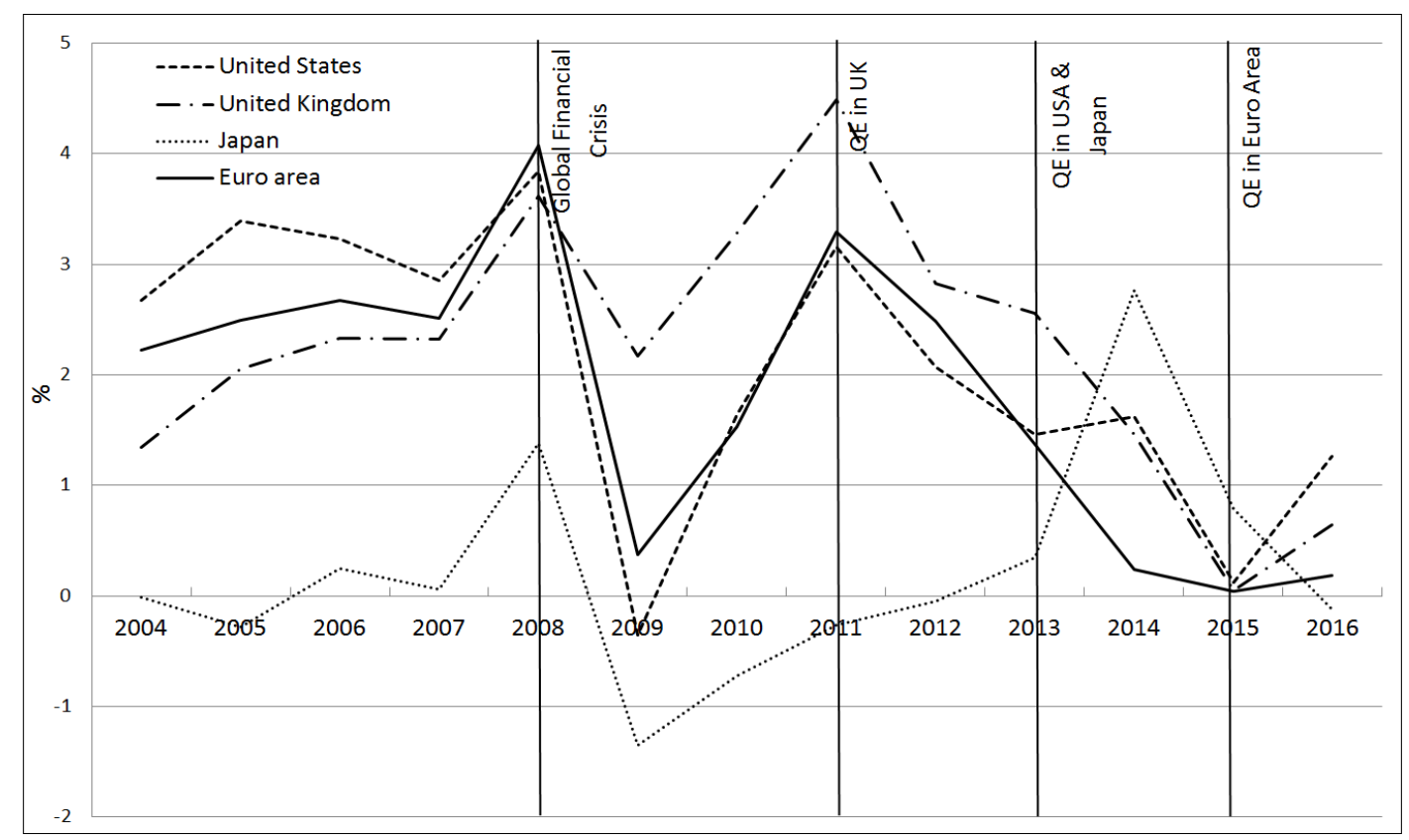

Figure 5: Inflation Rates (CPI Based) Source: World Bank, World Development Indicators, Accessed on June $20,2018$.

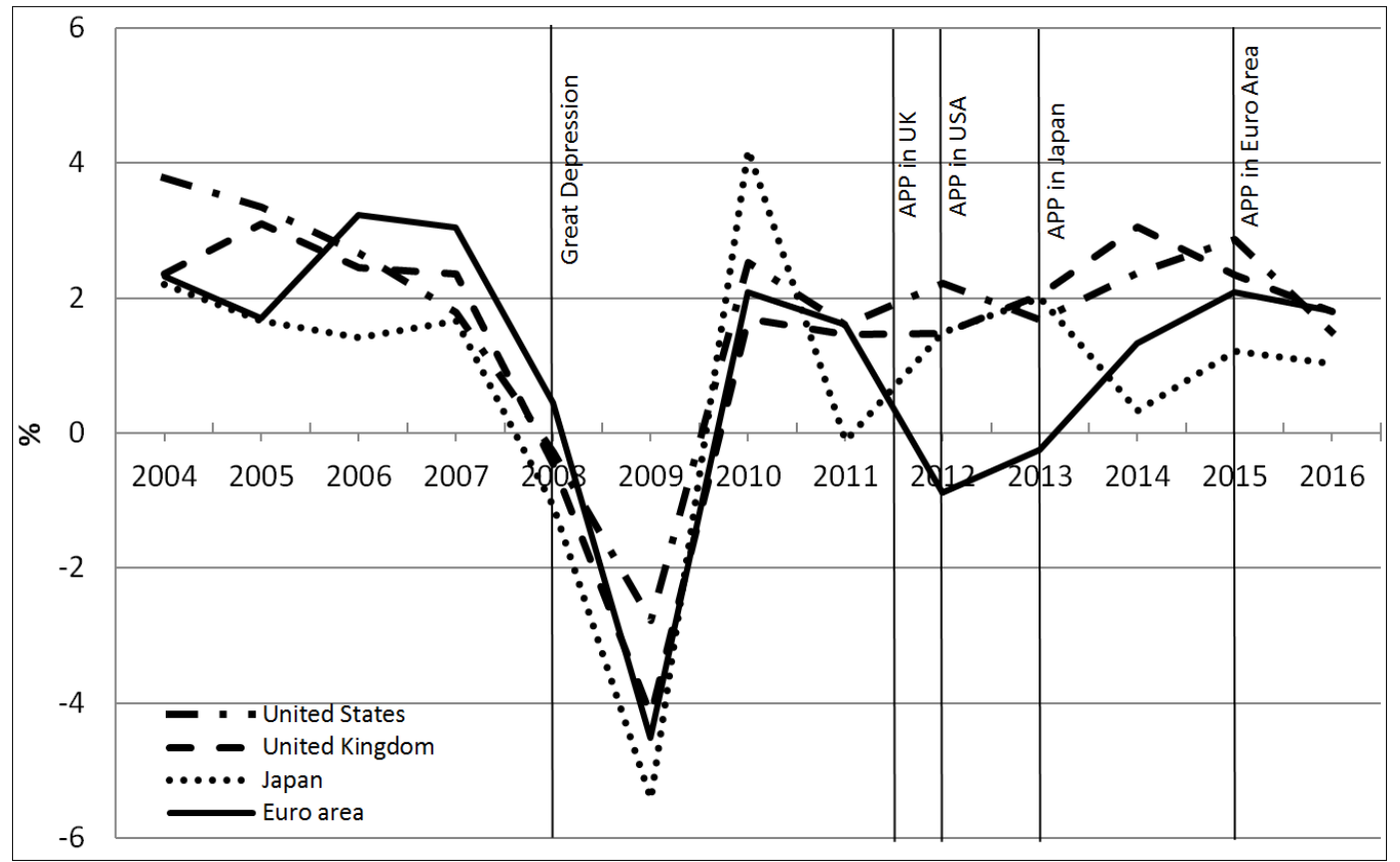

Figure 6: Real GDP Growth Source: World Bank, World Development Indicators, Accessed on June 20, 2018. 


\section{c. Real GDP growth}

Real GDP growth of all the economies had been negative in 2009. Though they recovered in 2010 owing to the UMP of the respective economies, they again slide into recession in the following year. What is common for USA, Japan and UK is that, there was a time lag in realizing positive growth effect following the LSAPs of the economies as growth rate initially dropped and then recovered. For Euro Area, similar trend is visible after the QE of ECB approved in January 2015.

\section{Literature Review}

The impacts of monetary policy like QE, a measure different from its conventional doctrine, have been investigated in a number of studies.

Baumeister and Benati (2013) examine the spreads of lower long-run bond for the recessionary period of 20009 applying a time-varying parameter structural VAR for the US, Euro area, Japan and the UK. The study identifies strong impact of a compression in the spread of long-term yield on inflation and growth of output. Such an unconventional policy measure, as the counterfactual simulations find, prevented the risks of deflation and collapses of output significantly both in the US and UK.

Chung et al. (2012) evaluates the effect of LSAPs undertaken by the Fed on the US economy with the help of simulations technique employing the Fed's FRB/US macroeconomic model augmented with a simple portfolio balance effects model and find that the LSAP1 and LSAP2 together raises the real GDP level and inflation by 3 percent and 1 percent respectively from the base set by the model. In a similar study, Chen et al. (2012) identifies an increase around 0.13 percent in real GDP and 0.03 percent in inflation of US following the LSAP2 programme. De Graeve and Theodoridis (2016) examines the impact of Fed's "Operation Twist" that includes the purchase and sale of bonds nearly $2 \%$ of US GDP and find the it causes US real GDP to rise by 0.6 percent and inflation by 0.3 percentage point. Gertler and Karadi (2013), in a calibrated version of their model, assess the output and inflation effects of US LSAP with a size of $2.5 \%$ of GDP and find that it has $1 \%$ and 1.5 percentage points impact on output and inflation, respectively remaining the policy rates unaltered, and $0.2 \%$ and 0.2 percentage points respectively for an active standard monetary policy rule and partially amends the effects of expansionary QE by increasing short-term rate.

While investigating the impact of LSAPs of Fed, Gagnon et al. (2011) find that it leads to a fall in long-term interest rates of securities included or not included in the asset purchase programme. Hamilton and Wu's (2012) estimation of bond pricing model also identify a fall of rate of interest. In another study on the long-term rate of interest rate, stock market and unemployment, Bhar, Malliaris, and Malliaris (2015) find that Fed's QE has a relatively strong effect on stock market compared to interest rate.

The VAR estimation aiming to simulate interest rate effect of QE for UK conducted by Joyce et al. (2011) reveals the evidence of fall in rate of interest rate in response to QE. Asset purchase program of BOE and its impact on UK GDP and inflation is examined by Kapetanios et al. (2012) using three VAR models including structural change in alternative ways. Results of the study indicate that the highest effect of QE on output level and annual CPI inflation are $1.5 \%$ and 1.25, respectively, a finding largely similar to those obtained by Bridges and Thomas (2012).

Studies on the macroeconomic effects of the ECB's policy interventions are also noteworthy. In one of the earlier work, Lenza et al. (2010) suggests that the compression of spreads owing to the unconventional policies of ECB has impact identical to the shock of standard monetary policy in normal times that causes significant change in loans and rates of interest, moderate effects on broad money, and hovers the enhancement of real activity and inflation. ECB's unconventional policy measures, as found by Giannone et al. (2012), increases the industrial production of euro-area by 2 percent than it would have been otherwise.

Sahuc (2016) adopts the model offered by Gertler-Karadi for the evaluation of asset purchases of ECB which was about 9\% of GDP of Euro Area. Sahuc (2016) finds that the policy rate that gives a maximum QE effect on output growth and inflation of 0.2 and 0.1 percentage points in 2015-16 raises the average output growth and inflation effect in 2015-16 to 0.6 and 0.6 percentage points if maintained for another year. And hence, Similar to Gertler and Karadi (2013), Sahuc (2016) based on his assessment emphasizes the significance of maintaining low short-run policy rates for extended period.

Schenkelberg and Watzka (2013) attempt to analyze the performance of QE program of BOJ. Influenced by a New Keynesian DSGE model, they rely on an SVAR with sign restrictions and identify that a shock produced by QE program was effective in cutting down the long-term interest rate and stimulating aggregate output in the short run. However, Baumeister and Benati (2013), based on a VAR with a built-in counterfactual interest rate spread scenario, determine a robust direct impact of QE on aggregate output.

Studies on the impact of QE on exchange rate include Ueda (2012), Glick and Leduc (2012), Neely (2012) and Fratzscher et al. (2018). Ueda (2012) shows that policy measures taken by the BOJ was successful to bring about an expected change in asset prices leaving insignificant impact on exchange rate. In case of US and UK, the study of Glick and Leduc (2012) demonstrates that QE announcements result in lower long-term interest rates and both 
the US dollar and British pound depreciates on the declaration dates. In a similar study, Neely (2012) finds that the first LSAP program by the Fed reduces yields of bond in other countries along with US and causes notable depreciation of the US dollar. In contrast, Fratzscher et al. (2018) opposes Neely (2012) and provides evidence that there was inflow of funds after the first LSAP that causes an appreciation of USD. However, he finds the second LSAP leading to the opposite results.

Kenourgios et al. (2015) study the impacts of the announcements of QE by the ECB, the BoJ and the BoE on dynamics of exchange rate employing intra-day data of three major exchange rates, namely- EUR/USD, GBP/USD and JPY/USD resorting a univariate APARCH $(1,1)$ model. The study concludes that QE programs of BoE and BoJ have a direct negative impact on their respective currencies without any impact on their volatility around the declaration date. It is also evident that ECB's QE announcement has a delayed devaluation effect on euro with a rise in the volatility around the announcement date.

The VAR estimation of Joyce et al. (2011) also identifies a remarkable drop in the stock index volatility at the onset of QE, a finding similar to Steeley and Matyushkin (2015).

\section{Data Sources}

The study employs quarterly data of real GDP growth; change in exchange rate index, inflation (CPI based), change in stock price index and yields of long-term bonds that are seasonally adjusted. Sources and periods are summarized below in Table 1 for central banks of different economies.

\begin{tabular}{|c|c|c|c|}
\hline Variables & Sources & Description & Period \\
\hline Real GDP Growth & FRED & \multirow{5}{*}{$\begin{array}{l}\text { Quarterly, } \\
\text { Seasonally } \\
\text { Adjusted }\end{array}$} & \multirow{5}{*}{$\begin{array}{l}\text { 2003Q1-2014Q4 } \\
\text { 2001Q3-2012Q4 } \\
\text { 2000Q1-2016Q4 } \\
\text { 2000Q1-20017Q2 }\end{array}$} \\
\hline Change in Exchange Rate Index & IMF & & \\
\hline Inflation (CPI Based) & IMF & & \\
\hline Change in Stock Price Index & FRED & & \\
\hline Yields of long-term bonds & FRED & & \\
\hline
\end{tabular}

Table 1: Variables- Sources and Periods

The study also identifies the recent QE programs of the respective central banks of the four economies in order to make projections in the preceding quarters. Table 2 below summarizes the recent QE programs of the central banks along with the projection period-

\begin{tabular}{|c|c|c|}
\hline Central Bank & Date of Announcement & Projection Period \\
\hline FED & December 2012 & 2013Q1-2014Q4 \\
\hline BOE & October 2011 & 2011Q4-2012Q4 \\
\hline BOJ & April 2013 & 2013Q2-2016Q4 \\
\hline ECB & January 2015 & 2015Q1-2017Q2 \\
\hline
\end{tabular}

Table 2: Recent QE and Projection Periods

\section{Methodology}

The structural VAR model considered for the study can be given as-

$$
A_{0} y_{t}=A_{1} y_{t-1}+A_{2} y_{t-2}+\cdots+A_{k} y_{t-k}+\varepsilon_{t}
$$

where $y_{t}$ is an $\mathrm{m} \times 1$ vector of endogenous variables and $\varepsilon_{t} \sim \mathrm{N}\left(0, \mathrm{I}_{\mathrm{m}}\right)$ with $\mathrm{E}\left(\varepsilon_{t} \mid y_{t-j}: j \geq 1\right)=0$.

The coefficient matrix $\mathrm{Aj}$ for $\mathrm{j}=0, \ldots \ldots, \mathrm{k}$ is an $\mathrm{m} \times \mathrm{n}$ matrix.

In our specification $\mathrm{y}_{\mathrm{t}}$ includes five variables: real GDP growth, change in exchange rate index, inflation (CPI based), change in stock price index, yields of long-term bonds. Inclusion of yields of long-term bonds is based on the assumption that the macroeconomic impacts of QE work entirely through its impact on yields of long-term bonds. As observed, yields of long term bond declined in the following years after pursuing QE.

Baseline simulation and simulation in a particular scenario designed to describe the impact when QE is absent making necessary adjustment in the long-term bond yields have been performed under the VAR specified above. Both the simulation types have been compared with the actual data of the variables used to explain the impact of QE on four major macroeconomic indicators of USA, UK, Japan and Euro Area. Necessary diagnostic checks have been performed for the VAR model for each of the economies separately and found to be suitable for making the projections. The models are found to be stable, residuals are white noise, and correlated, variables are free from short-run correlation and seasonality. 


\section{Empirical Results}

Model projection under baseline simulation represents performance of macroeconomic indicators due to QE. An alternative scenario tuning the long-term bonds yield yields performance of the indicators in the absence of QE. Results for different economies are presented in the subsequent figures.

\section{a. Experience from the USA}

The Federal Open Market Committee declared the per month open-ended asset purchases to increase from the amount of $\$ 40$ billion to $\$ 85$ billion on 12 December 2012. Its impacts have been studied from first quarter of 2013 onward until last quarter of 2014. To attain the alternative scenario, that is, the no-QE scenario, long term bond yields have been set unchanged over the forecast period at the rate observed at the end of 2012. Figure 7 compares the predictions for the major economic indicators under the scenarios of QE and no-QE. The figure shows that model projections defined under baseline simulation that considers QE programs into account fit reasonably well with no QE simulations for all the indicators.

Panel A shows the estimated effect of QE pursued by Fed on real GDP growth of USA. It is clear that the model projection based on baseline simulation deteriorates in the second half of the projection period, that is, in 2014 . The same is true for alternative scenario representing no QE. For the first two quarters, real GDP growth projection does not differ from model projection to no QE simulation, but for the rest of the period, model projection lies above the no QE scenario. It means that QE supports real GDP growth to perform better compared to no QE.

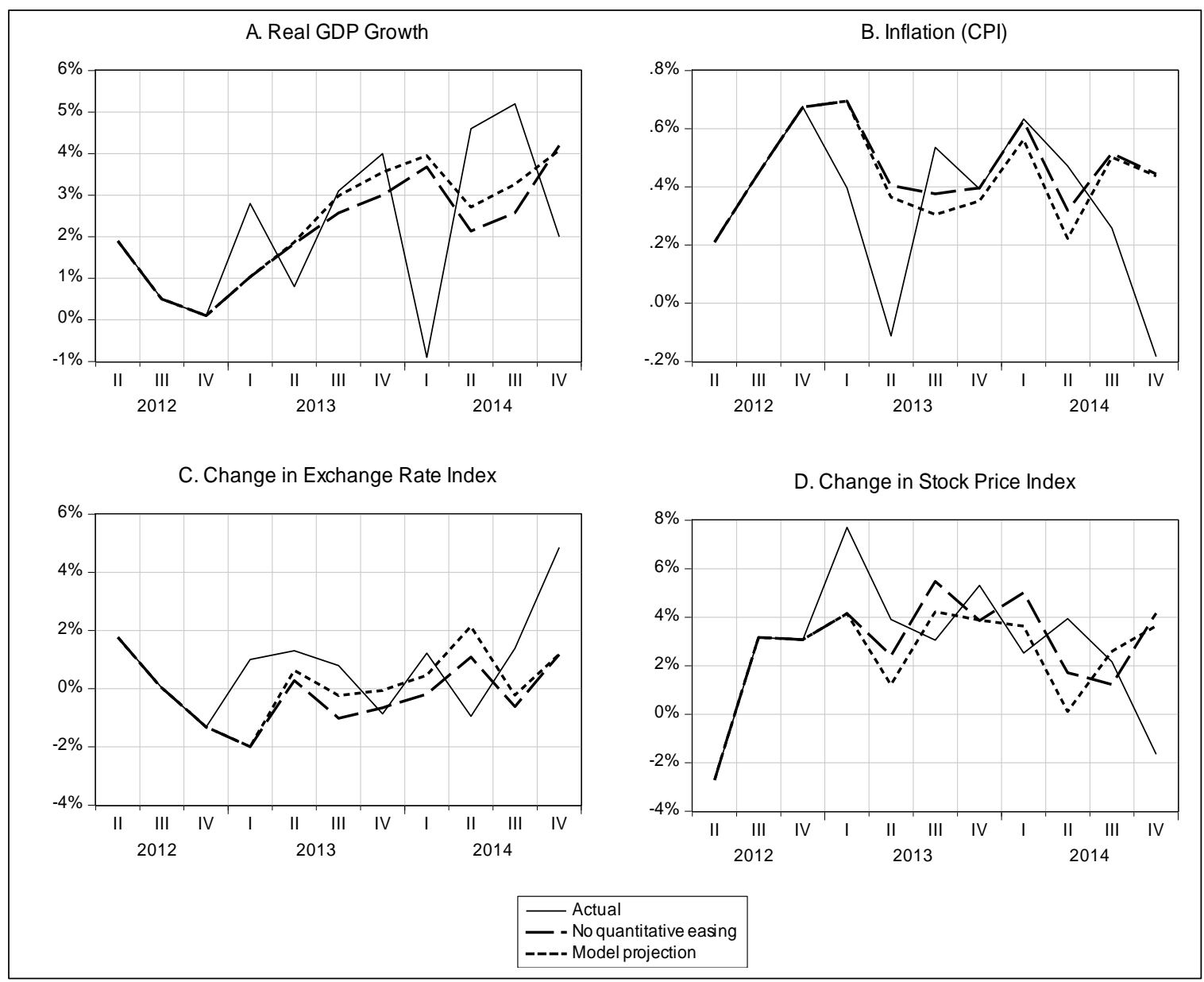

Figure 7: Simulations for the USA

The impact of Fed's QE on CPI inflation is illustrated by panel B. It shows that both the model projection and no QE scenario work good at the middle of the projection period, particularly from the second quarter of 2013 to second quarter of 2014. For the first two period, they are almost identical with that of the actual values. CPI inflation under model projection lies below the alternative scenario and therefore US CPI inflation would have been higher if Fed did not implement QE. The maximum impact of Fed's QE on CPI inflation was in the second quarter of 2014, 18 months later than the implementation of QE. It is obvious that Fed fails to maintain its target inflation rate of 2 percent despite the execution of QE, and no QE could bring about a better outcome at least in view of higher inflation expectation. 
It appears from panel $\mathrm{C}$ that both the QE and no QE simulation reasonably capture the trend in the actual data and they are less volatile. The minimum change in exchange rate index was in the first quarter of 2013 and the maximum change was in the second quarter of 2014. However, as the model projection and projection under no QE do not differ significantly, one cannot conclude that QE supports US dollar throughout the projection period.

Stock price index was volatile in the first and last few quarters of the projection period as illustrated in panel D. Apart from these two periods, stock market performs better with no QE as the projection backed by baseline simulation lay below the projection made under no QE scenario.

To conclude, while QE was found supportive for real GDP growth of USA, its impact on CPI inflation, change in exchange rate index and stock price index was not found to be conducive.

\section{b. Experience from the UK}

The second round QE of additional $£ 75$ billion announced by the BOE in October 2011 was extended by $£ 50$ billion in February 2012 and then by another $£ 50$ billion in July 2012 bringing the total amount to $£ 375$ billion. Thus the impacts of these QE announcements have been evaluated from the last quarter of 2011 to last quarter of 2012. The alternative scenario, that is, the no-QE scenario, is designed setting the long term bond yields at a level perceived at the end of 2011 along with the baseline scenario. Figure 8 compares the model projection with noQE simulation.

Panel A illustrates that as time passes away, both the model based and alternative scenario based projections of real GDP growth deteriorate. However, there is no significant difference found between the QE based and no-QE based projections at least for first three quarters of the projection timeline, while QE is less contributing to real GDP growth for the rest of the period. It indicates that real GDP growth would have been better in the absence of QE.

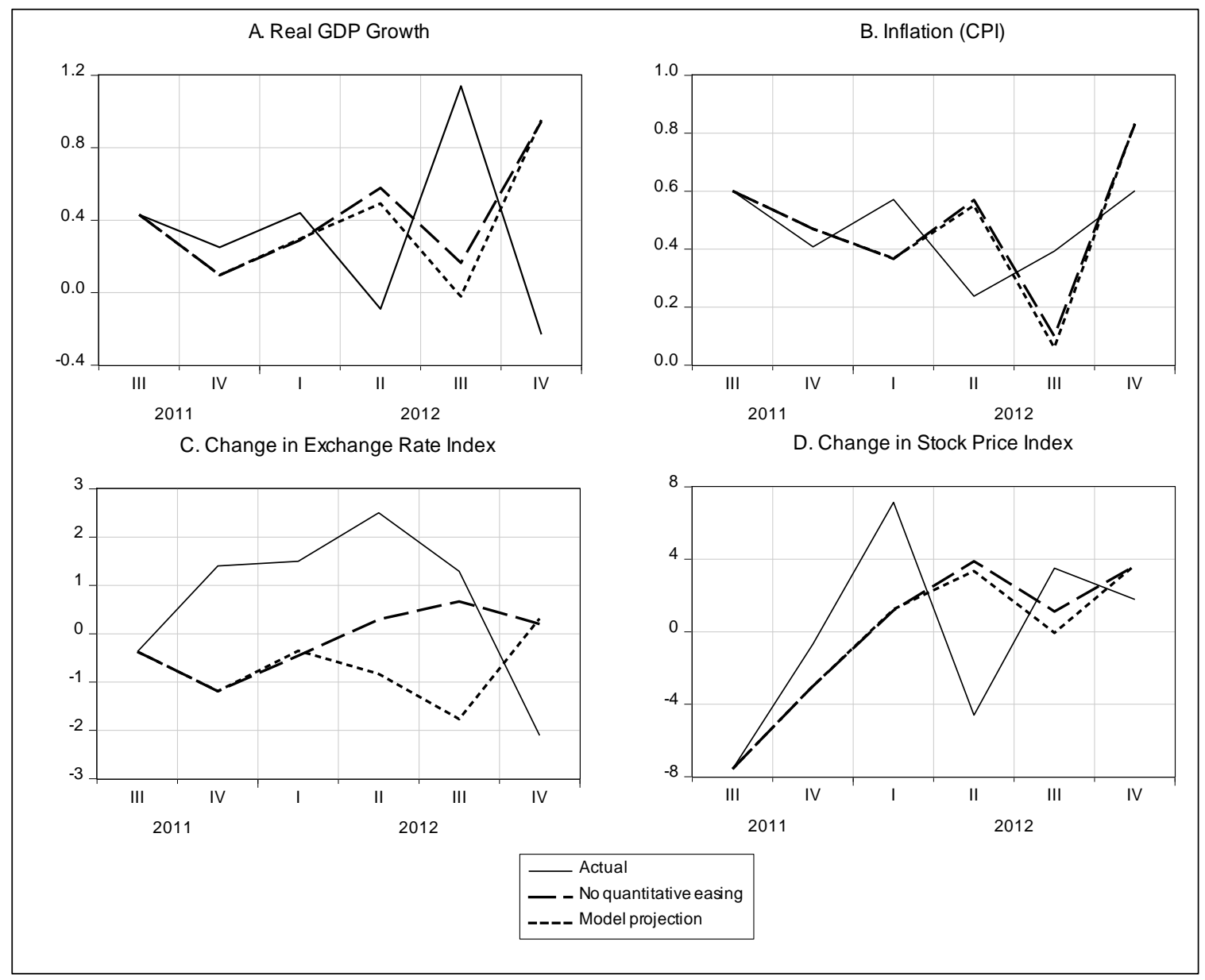

Figure 8: Simulations for the UK

From panel B, it is clear that projection of CPI based inflation under QE and no-QE simulations are very close to each other. As the projection does not differ between alternative scenarios, it stands to mean that the impact of QE on inflation of UK is negligible.

For the case of change in exchange rate index, it is obvious that both the baseline and no-QE simulation based projection fail to reflect the trend in the actual data which is somewhat volatile all through the projection period. 
As shown by panel C, results obtained under QE and no-QE scenario does not differ significantly for the first two quarters following the QE announcement and thus QE has insignificant influence on change in exchange rate index. However, from the first quarter of 2012, QE weakens the domestic currency of UK that starts to recover after the third quarter of 2012 and takes time till the end of the projection period.

Forecasting the change in stock price index of UK using different simulation types reveals that they well-capture the trend in the actual data. For the first six months after QE, there was no difference between model projections and no-QE scenario. But for the rest of the projection period, there was a clear indication that QE was not helpful for stock market development as the no-QE simulation lies above the baseline simulation.

Overall, QE is found to be unsuccessful in achieving desired result in terms of GDP growth and inflation expectations in UK. However, starting with an insignificant impact, QE gradually weakens the domestic currency of UK and its stock market.

\section{c. Experience from Japan}

The BOJ announced the expansion of its asset purchase program by 60 to 70 trillion Yen a year on April 2013, which was nominal in earlier years, only 2 trillion Yen a year. A further extension of its bond buying program to 80 trillion Yen a year was announced by BOJ on October 2014. The study thus examined the impact of the extension of asset purchase program from the second quarter of 2013 to the last quarter of 2016. In this respect, the model projection based on QE is compared with the no-QE simulation in Figure 9 considering the long-term bond yields constant at a rate maintained at the end of June 2013.

It is observed from panel A that projection both by baseline and no-QE simulation well fits with the trend in the actual data of real GDP growth for the first four and last seven quarters but deviates largely, predominantly opposite in nature, at the middle of the projection period. Actual data of real GDP growth mostly lie above the model forecasting. Moreover, projection by no-QE simulation lies entirely above the model based forecasting and therefore it is evident that real GDP growth would have been better if BOJ had not adopted QE.

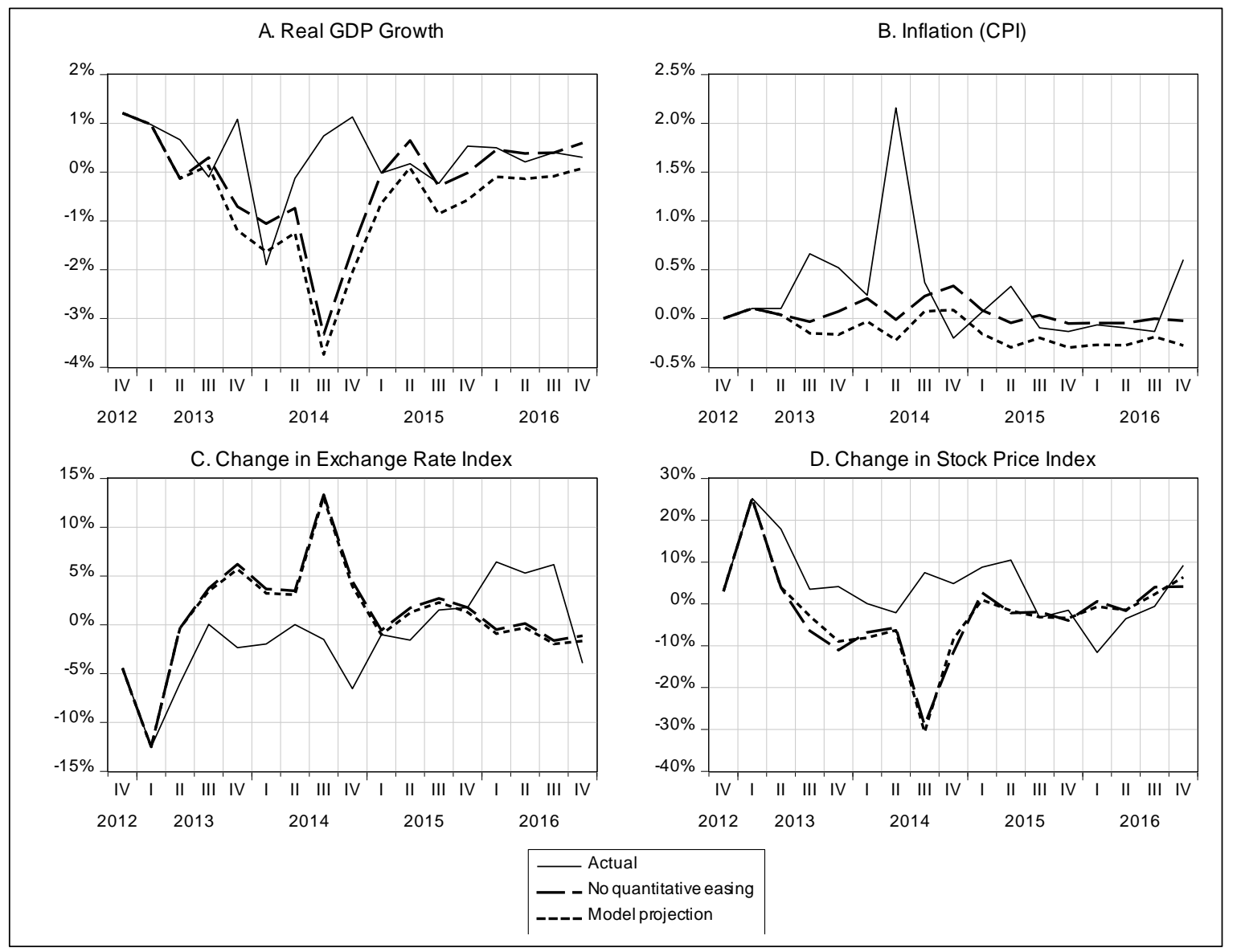

Figure 9: Simulations for Japan

Panel B shows the impact of BOJ's QE on CPI inflation in Japan. Clearly, QE of Japan fails to achieve the targeted 2 percent inflation rate. Moreover, the projected inflation under QE scenario is typically negative over the projection period and always lies below than that of no-QE scenario, which clearly indicates that no-QE would have been better for Japan in realizing inflation goals. 
The effects of QE on exchange rate index and stock price index are illustrated in panel C and D, respectively. Clearly, no noticeable difference is observed between the model projection and no-QE simulation throughout the forecast period both for the change in the index of exchange rate and stock prices and therefore BOJ's QE was not found to be effective in supporting the currency of Japan and its stock market.

In general, QE of BOJ's was not successful in bringing favorable outcomes for the major economic indicators considered for the study.

\section{d. Experience from the Euro Area}

Asset purchase program of ECB started in 2009 was insignificant and irregular till 2015. In January 2015, an expanded asset purchase program was announced by ECB in January 2015 with an aim to purchase euro-area bonds amounting to 60 billion euro per month from central governments, agencies and European institutions. The incentive was scheduled to last till September 2016 at the earliest with a total QE of no less than 1.1 trillion euro. ECB amplified its purchases of bond from $€ 60$ billion to $€ 80$ billion on monthly basis on March 2016 and started to comprise corporate bonds under the program of asset purchases and declared new ultra-cheap four-year loans to banks. The impacts of these expanded asset purchase program on major macroeconomic indicators are investigated from the first quarter of 2015 to the second quarter of 2017. Simulation results are shown in Figure 10.

If one compares the model projection and no-QE scenario based projection for real GDP growth in euro area as sown in panel A, it is difficult to identify a systematic pattern as none of them are consistently higher than the other. Thus, the simulation results indicate that the impact of QE on the real GDP growth of euro area is not certain.

Panel B demonstrations that the baseline projection and the no-QE simulation based projection are not discernable for the first two quarters of the forecast horizon. Otherwise, the model projection lies above the noQE simulation for the rest of the projection period which indicates that inflation in the Euro area would have been lower and impact would have been adverse if ECB had not undertaken QE.

The impact of QE on the change of exchange rate index of euro area is illustrated in panel C. Baseline simulation was identical to no-QE simulation for the first quarter of the projection horizon, while lies below it thereafter. It is a clear sign of the fact that QE did not support Euro throughout the projection horizon.

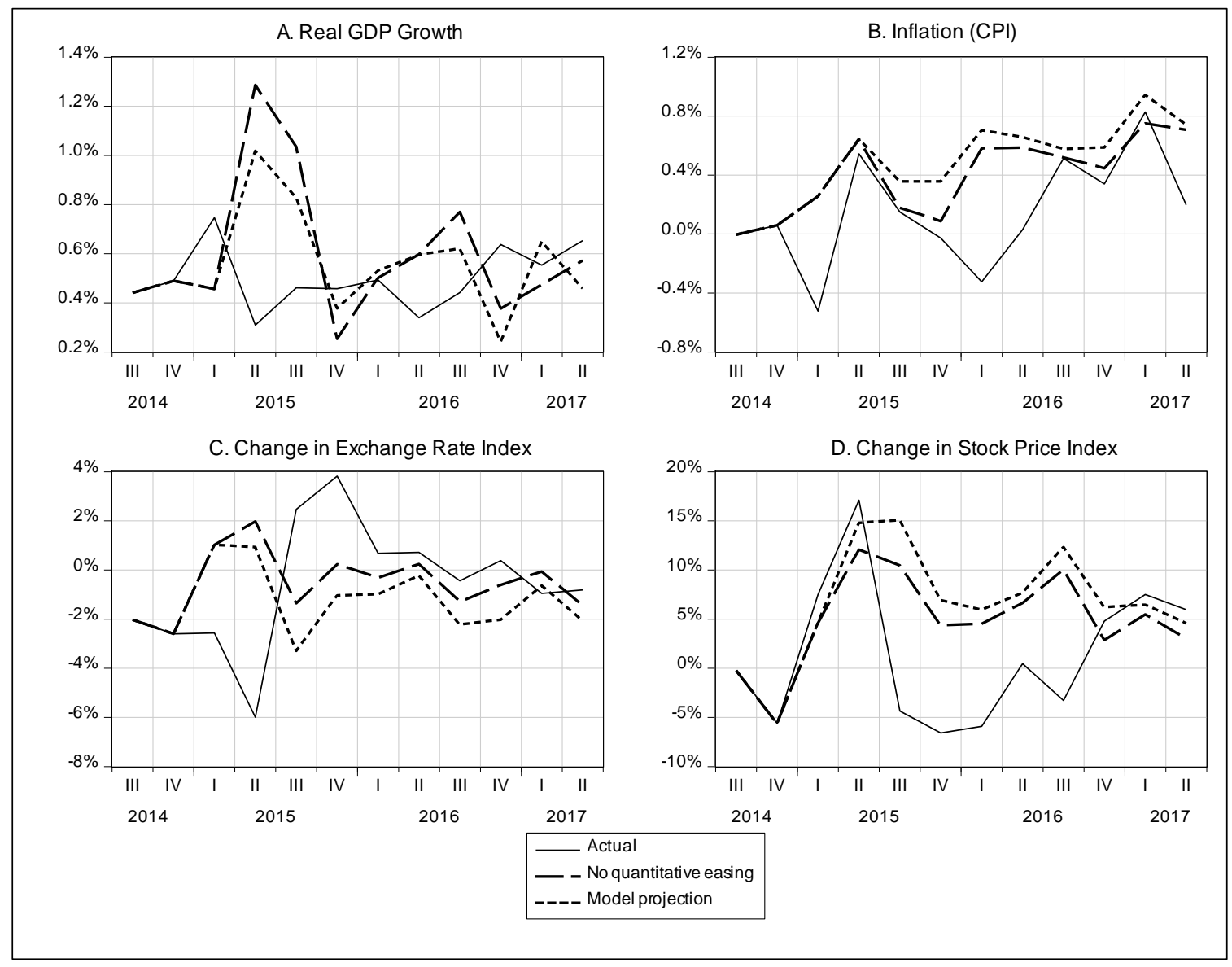

Figure 10: Simulations for Euro Area 
The effect of QE of ECB on stock market development is rather opposite as shown in panel D. Model projection of change in stock price index lies entirely above the no-QE simulation which suggests that stock market development would have been lower if QE had not been implemented by ECB.

Overall, while the impact of ECB's QE is uncertain on real GDP growth and adverse on CPI inflation and exchange rate, it is found to be favorable for the development of stock market of euro area.

\section{Conclusion}

The study examines the impact of UMP or QE announcements of major central banks of advanced economies on major economic indicators, namely output growth, inflation, exchange rate indices and stock market indices. Simulation results of the study suggest that QE was supportive for real GDP growth of USA. But the impact QE had on output growth was inconclusive for euro area and not supportive for the UK and Japan. However, the overall impact of QE on CPI inflation of these advanced economies was not found to be conducive. Except from euro area, QE weakened the domestic currencies and stock market development of USA, UK and Japan. One of the reasons for such results might be that the recessionary forces were strong enough to offset the forces of QE. Or, it might be due to inadequate scale of QE to address the recession of these advanced economies. At the same time, policy makers should think over other supplementary measures that can support and expedite the impact of QE in favourable directions to achieve the desired goals of the UMP.

\section{References}

- Baumeister, C., and L. Benati. (2013). Unconventional Monetary Policy and the Great Recession: Estimating the Macroeconomic Effects of a Spread Compression at the Zero Lower Bound. International Journal of Central Banking, 9(2), 165-211.

- $\quad$ Bhar, R., Malliaris, A. G. and Malliaris, M. (2015). The Impact of Large-Scale Asset Purchases on the S\&P 500 Index, Long-Term Interest Rates and Unemployment. Applied Economics. 47 (55), 6010-6018.

- Bouraoui, T. (2015). The effect of reducing quantitative easing on emerging markets. Applied Economics, 47(15), 1562-1573. https://doi.org/10.1080/00036846.2014.1000524

- $\quad$ Bridges, J. and Thomas, R. (2012). The Impact of QE on the UK Economy - Some Supportive Monetarist Arithmetic, Bank of England Working Paper No. 442. http://dx.doi.org/10.2139/ssrn.1992942

- Bundesbank, D. (2016). The macroeconomic impact of quantitative easing in the euro area. Deutsche Bundesbank Monthly Report, 29-53.

- Chen, H., V. Cúrdia, A. Ferrero (2012). The Macroeconomic Effects of Large-scale Asset Purchase Programmes, Economic Journal, 122(564), F289-F315. https://doi.org/10.1111/j.1468-0297.2012.02549.x

- $\quad$ Chung, H., Laforte, J. P., Reifschneider, D., \& Williams, J. C. (2012). Have we underestimated the likelihood and severity of zero lower bound events? Journal of Money, Credit and Banking, 44(s1), 47-82. https://doi.org/10.1111/j.1538-4616.2011.00478.x

- Clouse, James, Dale Henderson, Athanasios Orphanides, David Small, and Peter Tinsley, (2000). Monetary Policy when the Nominal Short-Term Interest Rate is Zero. The B.E. Journal of Macroeconomics, 3(1), https://doi.org/10.2202/1534-5998.1088.

- $\quad$ De Graeve, F., K. Theodoridis (2016). Forward guidance, quantitative easing, or both? National Bank of Belgium, Working Paper 305.

- $\quad$ Eggertsson, G. B. (2003). Zero bound on interest rates and optimal monetary policy. Brookings papers on economic activity, 2003(1), 139-233.

- Eggertsson, G. B. (2006). The Deflation Bias and Committing to Being Irresponsible. Journal of Money, Credit, and Banking, 38(2), 283-321. https://doi.org/10.1353/mcb.2006.0031

- $\quad$ Faust, J., Rogers, J. H., Wang, S. Y. B., \& Wright, J. H. (2007). The high-frequency response of exchange rates and interest rates to macroeconomic announcements. Journal of Monetary Economics, 54(4), 1051 1068. https://doi.org/10.1016/j.jmoneco.2006.05.015

- $\quad$ Fratzscher, M., Lo Duca, M., \& Straub, R. (2018). On the international spillovers of US quantitative easing. The Economic Journal, 128(608), 330-377. https://doi.org/10.1111/ecoj.12435

- Gagnon, J., Raskin, M., Remache, J., \& Sack, B. (2011). The Financial Market Effects of the Federal Reserve's Large Scale Asset Purchases. International Journal of Central Banking, 7(1), 3-43.

- $\quad$ Gertler, M. \& Karadi, P. (2013). QE 1 vs. 2 vs. 3: A Framework for Analyzing Large-Scale Asset Purchases as a Monetary Policy Tool, International Journal of Central Banking, 9(1), 5-53.

- Giannone, D., Lenza, M., Pill, H. and Reichlin, L. (2012). The ECB and the interbank market, The Economic Journal, 122(564), F467-86. https://doi.org/10.1111/j.1468-0297.2012.02553.x 
- Glick, R., \& Leduc, S. (2012). Central bank announcements of asset purchases and the impact on global financial and commodity markets. Journal of International Money and Finance, 31(8), 2078-2101. https://doi.org/10.1016/j.jimonfin.2012.05.009

- Haldane, A. G., Roberts-sklar, M., Wieladek, T., \& Young, C. (2016). QE: the story so far. Bank of England Working Paper No. 624. https://ssrn.com/abstract=2858204

- Hamilton, J. D., \& Wu, J. C. (2012). The effectiveness of alternative monetary policy tools in a zero lower bound environment. Journal of Money, Credit and Banking, 44(s1), 3-46. https://doi.org/10.1111/j.15384616.2011.00477.x

- Hausken, K., \& Ncube, M. (2013). Quantitative Easing and Its Impact in the US, Japan, the UK and Europe. London: Springer.

- Hohberger, S., Priftis, R., \& Vogel, L. (2017). The macroeconomic effects of quantitative easing in the Euro area: evidence from an estimated DSGE model. European University Institute, Economics Working Paper No ECO2017/04. http://cadmus.eui.eu/bitstream/handle/1814/45726/ECO_2017_04.pdf

- Joyce, M., Lasaosa, A., Stevens, I., \& Tong, M. (2011). The financial market impact of quantitative easing in the United Kingdom. International Journal of Central Banking, 7(3), 113-161.

- Joyce, M., Miles, D., Scott, A., \& Vayanos, D. (2012). Quantitative Easing and Unconventional Monetary Policy - An Introduction. The Economic Journal, 122(1), 45-64. https://doi.org/10.1111/j.14680297.2012.02551.x.

- $\quad$ Kapetanios, G., Mumtaz, H., Stevens, I. and Theodoridis, K. (2012). Assessing the economy-wide effects of quantitative easing, The Economic Journal, 122(564), F316-47. https://doi.org/10.1111/j.14680297.2012.02555.x

- Kenourgios, D., Papadamou, S., \& Dimitriou, D. (2015). On quantitative easing and high frequency exchange rate dynamics. Research in International Business and Finance, 34, 110-125. https://doi.org/10.1016/j.ribaf.2015.01.003

- Lenza, M., Pill, H. and Reichlin, L. (2010). Monetary policy in exceptional times, Economic Policy, 25(62), 295-339. https://doi.org/10.1111/j.1468-0327.2010.00240.x

- Maggio, D. M., Kermani, A., \& Palmer, C. (2016). How Quantitative Easing Works: Evidence on the Refinancing Channel. NBER Working Paper No. 22638. https://doi.org/10.3386/w22638

- Michaelis, H., \& Watzka, S. (2017). Are there differences in the effectiveness of quantitative easing at the zero-lower-bound in Japan over time? Journal of International Money and Finance, 70, 204-233. https://doi.org/10.1016/j.jimonfin.2016.08.008

- Mishkin, F. (1996). The Channels of Monetary Transmission: Lessons for Monetary Policy. NBER Working Papers No. 5464. Cambridge, MA: NBER.

- Neely, C. (2012). The large-scale asset purchases had large international effects. Federal Reserve Bank of St. Louis, Working Paper Series No. 2010-018D.

- Sahuc, J.-G. (2016). The ECB's asset purchase programme: A model-based evaluation, Economics Letters 145(C), 136-140. https://doi.org/10.1016/j.econlet.2016.06.009

- $\quad$ Schenkelberg, H. and Watzka, S. (2013). Real Effects of Quantitative Easing at the Zero Lower Bound: Structural VAR-Based Evidence from Japan. Journal of International Money and Finance, 33 (Mar), $327-$ 357. doi:10.1016/j.jimonfin.2012.11.020.

- Steeley, J. M., \& Matyushkin, A. (2015). The effects of quantitative easing on the volatility of the gilt-edged market. International review of financial analysis, 37, 113-128. https://doi.org/10.1016/j.irfa.2014.11.004

- Tobin, J. (1969). A General Equilibrium Approach to Monetary Theory. Journal of Money, 1(1), 15-29. https://doi.org/10.2307/1991374

- Ueda, K. (2012). The effectiveness of non-traditional monetary policy measures: the case of the Bank of Japan. The Japanese Economic Review, 63(1), 1-22. https://doi.org/10.1111/j.1468-5876.2011.00547.x 